\title{
Recent status and trends of the land bird avifauna on Saipan, Mariana Islands, with emphasis on the endangered Nightingale Reed-warbler Acrocephalus luscinia
}

\author{
RICHARD J. CAMP, THANE K. PRATT, ANN P. MARSHALL, \\ FRED AMIDON and LAURA L. WILLIAMS
}

\section{Summary}

The avifauna of the Mariana Islands, an archipelago in the western Pacific, faces the threats of rapid economic development and the spread of non-native species, particularly a devastating predator, Brown Tree Snake Boiga irregularis. In this paper, we examine the status and trends of the land bird fauna of Saipan Island based on three island-wide surveys conducted in 1982, 1997, and 2007. During this period, the human population on Saipan increased more than four-fold and much of the island has been developed. The surveys employed standard point-transect methods based on Distance Sampling. Remarkably, we found nearly all species of land birds - II native species and three introduced species - to be common or abundant. The exception was the Micronesian Megapode Megapodius laperouse, a historically rare species that was not observed on the 2007 survey, although it does persist on Saipan and other Mariana islands. A comparison of species densities among the three surveys showed that seven species, mainly fruit and seedeaters, had increased and three species of insectivorous birds had decreased - Rufous Fantail Rhipidura rufifrons, Nightingale Reed-warbler Acrocephalus luscinia, and Golden White-eye Cleptornis marchei. Of these three, Nightingale Reed-warbler is listed as 'Endangered' on the IUCN Red List and as an Endangered Species by the U.S. Fish and Wildlife Service. Reed-warbler densities on Saipan decreased by more than half between 1982 and 2007. Although point transect sampling worked well for this species, density estimates and trends assessment could be improved by reallocating sampling stations among habitats and by more frequent sampling.

\section{Introduction}

The Mariana Islands, an archipelago of 15 islands east of the Philippines, is one of the Endemic Bird Areas of the Pacific identified by BirdLife International (Stattersfield et al. 1998). The native land bird avifauna is composed of 19 species, of which 16 are Restricted Range species (Stattersfield et al. 1998) and 1o are endemic to the archipelago. Most of the endemic birds are closely related to species on other nearby Pacific islands, except for the Golden White-eye which is a monotypic genus. Over the past several centuries, the Mariana avifauna has withstood environmental changes brought about by ever-increasing human settlement of the islands. Matters changed after World War II with the introduction of the Brown Tree Snake to Guam, where it eliminated most bird species and decimated the rest ( 13 of 22 native breeding birds were lost from Guam; Rodda and Savidge 2007).

Hope for the remaining Mariana avifauna now lies with the islands north of Guam - Rota, Aguiguan, Tinian, and Saipan - the main islands of the Commonwealth of the Northern Mariana 
Islands (CNMI; Figure 1). Although there have been recent reports of the Brown Tree Snake from some CNMI islands, particularly from the most populous island, Saipan, surveys to date have not demonstrated that this notorious bird predator has established a breeding population in the CNMI (Rodda and Savidge 2007). Nevertheless, it would seem that without intensive interdiction

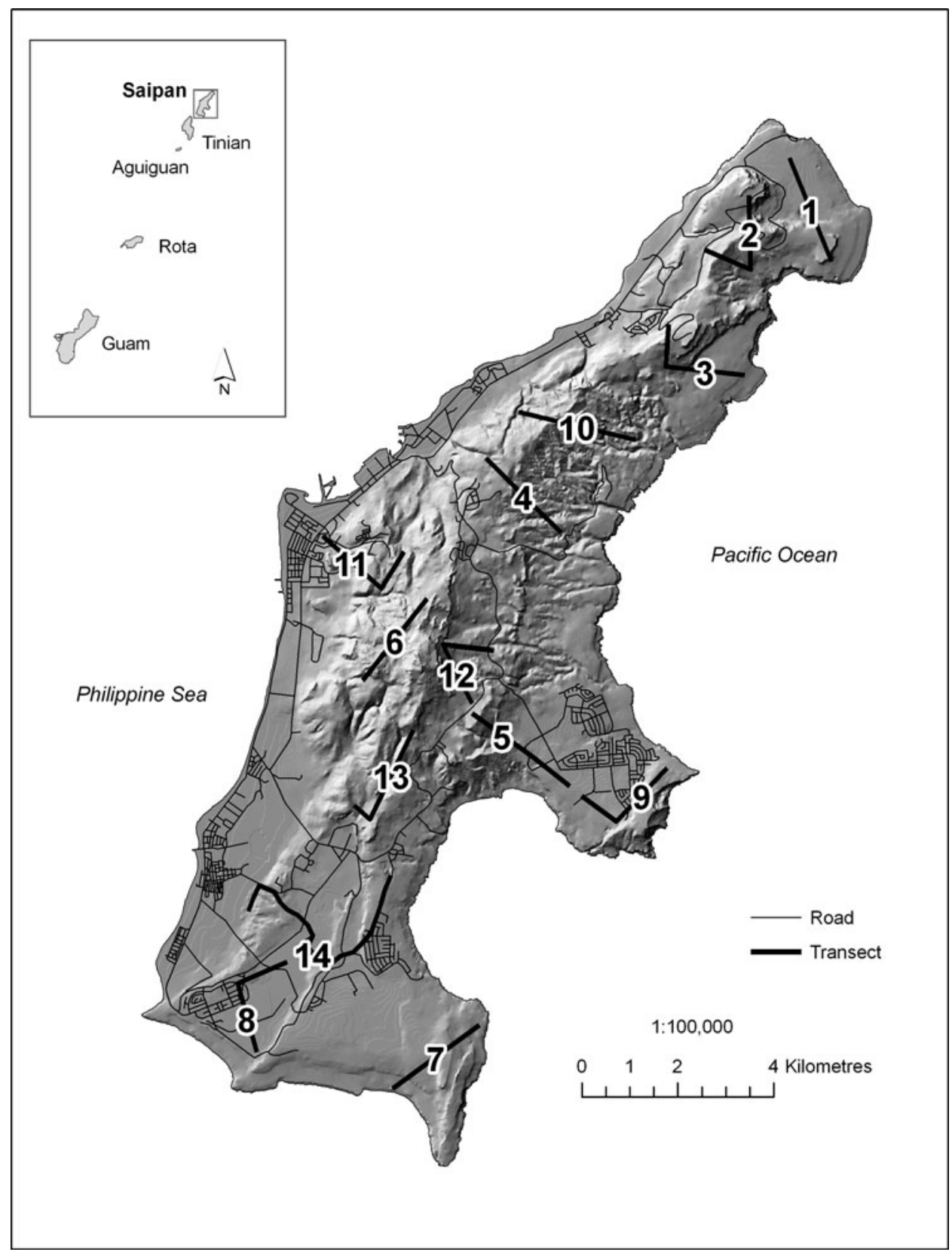

Figure 1. Island of Saipan showing the survey transects. 
efforts, the snake will soon establish itself on Saipan, if it has not already done so (Colvin et al. 2005). Other invasive non-native species are also a concern. Scarlet Gourd Coccinia grandis is an invasive herbaceous vine that was probably introduced to Saipan in 1998, where it has altered bird habitat by smothering native and non-native forest, Tangantangan Leucaena leucocephala thicket, and other vegetation. These newly emerging alien species have arrived with the exchange of goods and trade as part of ongoing globalisation (Heuttmann and Czech 2006). Apart from the Brown Tree Snake and other non-native species, the main threat to Saipan's native birds has been extensive economic development of the island with resulting transformation of forested and agricultural habitats to residential housing, resorts, golf courses, and other commercial building.

Invasive species and economic development have been the cause for extinction or depletion of numerous bird species in Oceania and would seem to bode poorly for birds in the CNMI as well (BirdLife International 2000). Many of the 12 species of native land birds on Saipan are believed to be common and doing fairly well (Table 1; Reichel and Glass 1991). Nevertheless, five species appear on the IUCN Red List (BirdLife International 2000, updated at www.iucnredlist.org and viewed 29 December 2008). The Golden White-eye is designated as 'Critically Endangered'.

Table 1. List of bird species and numbers of birds detected from point-transect surveys in three different years, Saipan, Mariana Islands. Nomenclature for widespread species follows the American Ornithologists' Union (1983) and for restricted range species, BirdLife International (2000, updated at www.iucnredlist.org). Density estimates were produced for species in bold. Class includes: native land bird $(\mathrm{N})$, introduced land bird (I), domestic (D), seabird (S), vagrant (V), and water bird (W).

\begin{tabular}{|c|c|c|c|c|c|}
\hline Species Name & Scientific Name & Class & 1982 & 1996 & 2007 \\
\hline White-tailed Tropicbird & Phaethon lepturus & $\mathrm{S}$ & 18 & 5 & 3 \\
\hline Yellow Bittern & Ixobrychus sinensis & $\mathbf{N}$ & 14 & 40 & 30 \\
\hline Pacific Reef Heron & Egretta sacra & W & o & 1 & o \\
\hline Lesser Cattle Egret & Bubulcus ibis & W & o & 2 & 1 \\
\hline Micronesian Megapode & Megapodius laperouse & $\mathrm{N}$ & 5 & 1 & $\mathrm{O}$ \\
\hline Red Junglefowl & Gallus gallus & $\mathrm{D}$ & 327 & 2 & 47 \\
\hline Common Peafowl & Pavo cristatus & $\mathrm{D}$ & 6 & o & $\mathrm{o}$ \\
\hline Wild Turkey & Meleagris gallopavo & $\mathrm{D}$ & 5 & $\mathrm{o}$ & 1 \\
\hline Northern Bobwhite & Colinus virginianus & $\mathrm{D}$ & o & o & 1 \\
\hline Common Moorhen & Gallinula chloropus & W & 1 & o & o \\
\hline Pacific Golden Plover & Pluvialis fulva & W & 6 & o & 1 \\
\hline Black Kite & Milvus migrans & $\mathrm{V}$ & $\mathrm{o}$ & 1 & o \\
\hline Brown Noddy & Anous stolidus & $\mathrm{S}$ & o & 31 & 29 \\
\hline Black Noddy & Anous minutus & $\mathrm{S}$ & $\mathrm{o}$ & o & 12 \\
\hline Common White-tern & Gygis alba & $\mathrm{S}$ & 574 & 257 & 395 \\
\hline Rock Dove & Columba livia & $\mathrm{D}$ & $\mathrm{o}$ & 10 & 2 \\
\hline Island Collared-dove & Streptopelia bitorquata & I & 29 & 74 & 89 \\
\hline White-throated Ground-dove & Gallicolumba xanthonura & $\mathbf{N}$ & 11 & 24 & 172 \\
\hline Mariana Fruit-dove & Ptilinopus roseicapilla & $\mathbf{N}$ & 487 & 319 & 367 \\
\hline Guam Swiftlet & Collocalia bartschi & $\mathrm{N}$ & 106 & 153 & 266 \\
\hline Collared Kingfisher & Todiramphus chloris & $\mathbf{N}$ & 339 & 345 & 297 \\
\hline Micronesian Myzomela & Myzomela rubratra & $\mathbf{N}$ & 549 & 317 & 474 \\
\hline Rufous Fantail & Rhipidura rufifrons & $\mathbf{N}$ & 1128 & 691 & 474 \\
\hline Nightingale Reed-warbler & Acrocephalus luscinia & $\mathbf{N}$ & 287 & 190 & 118 \\
\hline Bridled White-eye & Zosterops saypani & $\mathbf{N}$ & 1864 & 1702 & 1750 \\
\hline Golden White-eye & Cleptornis marchei & $\mathbf{N}$ & 749 & 426 & 373 \\
\hline Micronesian Starling & Aplonis opaca & $\mathbf{N}$ & 98 & 169 & 253 \\
\hline Eurasian Tree Sparrow & Passer montanus & $\mathbf{I}$ & 41 & 371 & 324 \\
\hline Orange-cheeked Waxbill & Estrilda melpoda & $\mathbf{I}$ & o & 0 & 75 \\
\hline
\end{tabular}


The Micronesian Megapode, Mariana Fruit-dove Ptilinopus roseicapilla, and Nightingale Reedwarbler are listed as 'Endangered', and the White-throated Ground-dove Gallicolumba xanthonura is 'Near Threatened'. The U.S. Fish and Wildlife Service (2004) lists the megapode, reed-warbler and Guam Swiftlet Collocalia bartschi as Endangered Species.

The aim of this paper is to examine the status and trends of native Saipan land birds over the past 25 years based on a comparison of three surveys. A baseline survey of Saipan was undertaken in 1982 by Engbring et al. (1986), and two follow-up surveys that have not yet been reported were conducted in 1997 (U.S. Fish and Wildlife Service 1998a) and 2007. We analysed data from these surveys to produce estimates of population density and to assess species trends. We also make recommendations for the design of future surveys on Saipan.

A particular focus of this study was to determine the status of the 'Endangered' Nightingale Reed-warbler. This species is known from six islands in the Mariana archipelago, but it currently persists on only two islands - Saipan and Alamagan (Reichel et al. 1992, U.S. Fish and Wildlife Service 1998b, Berger et al. 2005). On Saipan, the reed-warbler population is limited by habitat loss and predation, especially from introduced rat species (Mosher 2006). The need to maintain habitat for this bird is conflicting with development pressures. The U.S. Fish and Wildlife Service and CNMI Division of Fish and Wildlife are formulating an island-wide conservation plan for the reed-warbler on Saipan, and an important first step is to determine the species' current status.

\section{Methods}

\section{Survey area}

Saipan is the largest of the CNMI islands at $119 \mathrm{~km}^{2}\left(15^{\circ} 12^{\prime} \mathrm{N}, 145^{\circ} 45^{\prime} \mathrm{E}\right)$. The island consists of low-lying plateaus and a rugged limestone ridge dominated by Mt. Takpochao (436 m). The vegetation of Saipan is mixed second-growth native forest, grassy savanna, and forest of introduced trees, mostly Tangantangan thickets (Falanruw et al. 1989). The little native vegetation that remains on Saipan has been greatly altered by centuries of human use and invasion of nonnative species (Engbring et al. 1986). An appreciation of the magnitude of environmental transformation of Saipan can be gained from the human population figures for this small island. Records show that the population rose by $429 \%$ for the 20 -year period from 1980 to 2000 (the most recent survey), by which time it had reached 62,393 people and was still growing (U.S. Bureau of the Census 1981, U. S. Census Bureau 2001).

\section{Bird surveys}

The baseline survey in 1982 sampled a total of 244 stations on 14 transects with representative island-wide coverage across geography and habitats, except that older urban areas were not included (Engbring et al. 1986). Effects of excluding urban areas may result in under-estimating abundances of human commensal species, such as Island Collared-dove Streptopelia bitorquata and Eurasian Tree Sparrow Passer montanus. Transects were originally located using a randomsystematic method when applicable (see Engbring et al. 1986 for details). The same transects were relocated and resurveyed during both the 1997 and 2007 surveys. An additional four stations were sampled during the 2007 survey for a total of 248 stations but these additional stations were dropped for repeated measures analysis, for a total of 242 stations repeatedly surveyed (see also Population trends below).

All three surveys followed standard methods for point-transect distance sampling, consisting of 8-minute counts where horizontal distances to all birds heard and/or seen were measured and recorded (see Engbring et al. 1986 for details). Sampling conditions recorded included cloud cover, rain, wind, noise level, and habitat type, and these were later used as covariates in density calculations (see Population status below). Counts commenced at sunrise and continued for up to four hours and were conducted only under favourable weather conditions. Upon completing each 
count, the habitat around the sampling station was subjectively classified into one of six habitat types: golf course, limestone forest, open, residential, secondary forest, or Tangantangan thicket, following procedures established by Engbring et al. (1986). Later, questionable classifications were compared to vegetation maps (Falanruw et al. 1989, Liu and Fischer 2006) and to recent satellite imagery and assigned the dominant vegetation category. Two observers surveyed each station in 1982 and 2007, and one observer surveyed each station in 1997. Only data from one counter was used for each station from the 1982 survey and the best counters were identified based on their experience and survey proficiency. Density estimates for the 2007 survey used data from both counters, and sampling effort was adjusted by the number of counts.

\section{Population status}

Population status was expressed as a calculated density (birds $\mathrm{km}^{-2}$ ) and number of birds (habitat-specific density multiplied by habitat area; Liu and Fischer 2006). Densities were calculated using the program DISTANCE version 5.0 release 2 (Thomas et al. 2006) from species-specific global detection functions where data were post-stratified by survey. Data were right-truncated to maximise model fit (Buckland et al. 2001: 16), and the model with the lowest AIC was used to select the detection function that best approximated the data. Candidate models included half-normal and hazard-rate detection functions with expansion series of order two (Buckland et al. 2001: 361, 365). Sampling covariates were modelled in the multiple-covariate distance engine of DISTANCE (Marques and Buckland 2004, Thomas et al. 2006). Covariates (see Bird surveys above) were used to generate the global detection function when the best approximating model was improved by four or more AIC units (Appendix 1 in Supplementary materials). Variances and confidence intervals were derived by bootstrap methods in DISTANCE from 999 iterations (Thomas et al. 2006). Survey-specific density by station values were generated for the habitat association analysis (see Habitat associations below) from the global detection function using the post-stratification by sample option. The project file and associated metadata are available from the authors by request.

\section{Population trends}

Change in bird densities was assessed with repeated measures analysis of variance (ANOVA: PROC MIXED; SAS Institute Inc., Cary, NC). To stabilise the error variances, densities by station were $\log$ transformed after a constant of $I$ was added, to avoid $\ln (0)$. Stations were treated as the random factor, and because the number of repeated measures was too small to fit a covariance model, we assumed the variance-covariance structure was a compound symmetry, homogeneous variance model (Littell et al. 1996). The degrees of freedom were adjusted using the KenwardRoger adjustment statement and a Tukey's adjustment was used to control alpha $=0.05$ for multiple-comparison procedures.

Reliable trends detection is essential to conservation and is ultimately dependent on the statistical power of observing a certain trend over a specific time period. Assessing the prospective statistical power of a monitoring programme is one measure of sampling the programme's effectiveness. We estimated the power to detect a $50 \%$ decline in population sizes over a 25 -year period with the program TRENDS (Gerrodette 1987, 1991). Variance was estimated by regressing the annual densities by year for each species. We calculated the coefficient of variation (CV) by dividing the regression standard error by the grand mean density of the three surveys. We assumed a linear decline in the population and a constant CV in abundance; the small sample size precluded identifying if other models were more appropriate. We calculated power using a onetailed $t$-test because detecting declines in a native population is appropriate for monitoring and conservation objectives. We considered adequate power to detect trends at levels $>80 \%$ with a 0.1 alpha-level (Di Stefano 2003). 
Power to detect trends may be improved by increasing the number of stations sampled, in addition to modifying the other parameters that influence power (i.e., increase estimator precision, increase the magnitude change and relax alpha). In calculating power, we set relatively liberal parameter levels (i.e., magnitude of $50 \%$ over 25 years, one-tailed test at 0.1 alpha-level); therefore, we concentrated on reducing the components of variance associated with the encounter rate and the slope of the probability density function by increasing the sample size. We calculated the number of stations required to yield reliable CV levels with equation 7.14 from Buckland et al. (2001:245). The required number of stations was estimated by

$$
k=\left(\frac{b}{\{c v(\hat{D})\}^{2}}\right) \bullet\left(\frac{k_{0}}{n_{0}}\right)
$$

Where $b$ was assumed to be 3 , the required coefficient of variation was $10 \%$, and $k_{0}$ and $n_{0}$ were the mean number of stations sampled and birds detected from the three surveys.

\section{Nightingale Reed-warbler habitat associations}

Mosher (2006) identified that habitat loss represents a leading factor limiting Nightingale Reedwarbler populations; therefore, we calculated reed-warbler densities by habitat and year to investigate how densities change through time. We compared Nightingale Reed-warbler densities using an orthogonal contrast among suitable and less suitable habitats and years. We defined suitable habitat to include open, secondary forest, and Tangantangan thicket, whereas golf course, limestone forest, and residential were classified as less suitable habitat (Craig 1992, Mosher 2006). The contrast was assessed from a 2-way repeated measures ANOVA (PROC MIXED; SAS Institute Inc., Cary, NC) with the same options used in the repeated measures trends models.

\section{Results}

In total 29 species were detected in the three surveys, including all 12 species of native land birds and three introduced species (Table 1). The introduced Orange-cheeked Waxbill Estrilda melpoda became established on Saipan between the 1997 and 2007 surveys (Johnson 2003). Also recorded were four species of resident seabird, four species of resident and migratory wader and shorebird, and a vagrant hawk (Black Kite Milvus migrans). These latter nine species, plus four species of domestic galliform and Rock Dove Columba livia, will not be considered further.

\section{Population density and size}

We were able to produce density estimates for 13 species (Table 2, Appendix 2 in Supplementary materials). The remaining 16 bird species had too few detections to reliably model or are more appropriately surveyed by other methods. Density estimates varied widely among species. In the most recent survey (2007), the super-abundant Bridled White-eye Zosterops saypani had the highest density $\left(4,713\right.$ birds $\mathrm{km}^{-2} ; 95 \%$ CI 3,983-5,489), followed by the Golden White-eye (712 birds km ${ }^{-2} ; 95 \%$ CI 535-975). Lowest densities were for Island Collared-dove (37 birds $\mathrm{km}^{-2} ; 95 \%$ CI 24-55), Collared Kingfisher Todiramphus chloris (26 birds km ${ }^{-2} ; 95 \%$ CI 17-39), and Yellow Bittern Ixobrychus sinensis (11 birds km ${ }^{-2} ; 95 \%$ CI 5-21). Of the native land birds, all occurred in sufficient numbers to allow meaningful density estimates to be calculated, except for the Micronesian Megapode, which was recorded during the fieldwork period but not during the counts. 
Table 2. Population density (birds $\mathrm{km}^{-2} \pm \mathrm{SE}$, with $95 \% \mathrm{CI}$ ) and abundance (2007 only) estimates for Saipan land birds from three point-transect surveys. Abundance was calculated as the sum of density by habitat type times the area of habitat types, with 95\% CI (area of habitat types from Liu and Fisher 2006).

\begin{tabular}{|c|c|c|c|c|}
\hline Species & 1982 & 1997 & 2007 & 2007 Abundance \\
\hline Yellow Bittern & $\begin{array}{l}2.9 \pm 1.4 \\
(0-5.9)\end{array}$ & $\begin{array}{l}20.3 \pm 6.9 \\
(9.5-36.4)\end{array}$ & $\begin{array}{l}11.4 \pm 4.3 \\
(4.8-21.2)\end{array}$ & $\begin{array}{l}1,385 \\
(317-3,231)\end{array}$ \\
\hline Island Collared-dove & $\begin{array}{l}7.4 \pm 2.3 \\
(3.4-12.5)\end{array}$ & $\begin{array}{l}30.4 \pm 7.2 \\
(17.8-45.8)\end{array}$ & $\begin{array}{l}37.4 \pm 7.8 \\
(24.1-54.7)\end{array}$ & $\begin{array}{l}4,476 \\
(1,965-7,962)\end{array}$ \\
\hline White-throated Ground-dove & $\begin{array}{l}6.1 \pm 2.2 \\
(2.3-10.7)\end{array}$ & $\begin{array}{l}16.7 \pm 4.6 \\
(8.4-26.4)\end{array}$ & $\begin{array}{l}100.5 \pm 13.2 \\
(77.1-127.9)\end{array}$ & $\begin{array}{l}11,800 \\
(7,468-16,862)\end{array}$ \\
\hline Mariana Fruit-dove & $\begin{array}{l}67.1 \pm 6.8 \\
(54.6-81.0)\end{array}$ & $\begin{array}{l}65.2 \pm 6.3 \\
(53.3-77.2)\end{array}$ & $\begin{array}{l}65.5 \pm 7.1 \\
(53.0-79.8)\end{array}$ & $\begin{array}{l}9,723 \\
(7,129-13,050)\end{array}$ \\
\hline Collared Kingfisher & $\begin{array}{l}25.3 \pm 5.2 \\
(16.4-37.8)\end{array}$ & $\begin{array}{l}36.5 \pm 7.3 \\
(23.9-54.8)\end{array}$ & $\begin{array}{l}25.8 \pm 5.5 \\
(16.8-39.1)\end{array}$ & $\begin{array}{l}3,005 \\
(1,783-4,617)\end{array}$ \\
\hline Micronesian Myzomela & $\begin{array}{l}360.1 \pm 57.6 \\
(280.9-493.9)\end{array}$ & $\begin{array}{l}386.7 \pm 63.8 \\
(300.1-530.4)\end{array}$ & $\begin{array}{l}482.3 \pm 76.7 \\
(383.5-651.5)\end{array}$ & $\begin{array}{l}64,351 \\
(47,192-86,556)\end{array}$ \\
\hline Rufous Fantail & $\begin{array}{l}885.8 \pm 113.6 \\
(751.0-1,112.6)\end{array}$ & $\begin{array}{l}790.0 \pm 109.1 \\
(658.1-992.0)\end{array}$ & $\begin{array}{l}469.07 \pm 63.0 \\
(394.1-601.5)\end{array}$ & $\begin{array}{l}52,318 \\
(39,703-70,057)\end{array}$ \\
\hline Nightingale Reed-warbler & $\begin{array}{l}57.7 \pm 6.0 \\
(46.2-69.8)\end{array}$ & $\begin{array}{l}40.2 \pm 4.5 \\
(31.8-49.3)\end{array}$ & $\begin{array}{l}22.5 \pm 2.8 \\
(17.2-28.2)\end{array}$ & $\begin{array}{l}2,742 \\
(1,686-3,956)\end{array}$ \\
\hline Bridled White-eye & $\begin{array}{l}4,709.7 \pm 332.0 \\
(4,079.7-5,388.2)\end{array}$ & $\begin{array}{l}5,343 \cdot 9 \pm 407.2 \\
(4,588.6-6,178.4)\end{array}$ & $\begin{array}{l}4,713.3 \pm 387.0 \\
(3,982.7-5,488.9)\end{array}$ & $\begin{array}{l}534,029 \\
(427,858-650,667)\end{array}$ \\
\hline Golden White-eye & $\begin{array}{l}1,287.3 \pm 191.0 \\
(993.2-1,740.8)\end{array}$ & $\begin{array}{l}995.5 \pm 160.0 \\
(740.4-1,355.4)\end{array}$ & $\begin{array}{l}711.8 \pm 112.1 \\
(534.8-975.3)\end{array}$ & $\begin{array}{l}71,997 \\
(47,586-106,535)\end{array}$ \\
\hline Micronesian Starling & $\begin{array}{l}47.3 \pm 12.5 \\
(27.5-76.2)\end{array}$ & $\begin{array}{l}118.1 \pm 28.2 \\
(73.8-185.7)\end{array}$ & $\begin{array}{l}161.9 \pm 43.8 \\
(96.8-257.5)\end{array}$ & $\begin{array}{l}18,470 \\
(9,686-31,714)\end{array}$ \\
\hline Eurasian Tree Sparrow & $\begin{array}{l}48.9 \pm 16.4 \\
(21.5-84.8)\end{array}$ & $\begin{array}{l}495.1 \pm 85.2 \\
(341.7-685.7)\end{array}$ & $\begin{array}{l}386.3 \pm 93.5 \\
(241.9-614.1)\end{array}$ & $\begin{array}{l}75,484 \\
(46,529-113,122)\end{array}$ \\
\hline Orange-cheeked Waxbill & o & o & $\begin{array}{l}229.7 \pm 56.3 \\
(44.4-525.7)\end{array}$ & $\begin{array}{l}27,324 \\
(1,791-82,136)\end{array}$ \\
\hline
\end{tabular}

Because population size was a function of density, abundance patterns followed density. Populations of all species except the megapode ranged in 2007 from 428,000 to 651,000 Bridled White-eyes to $317-3,200$ Yellow Bitterns. In conclusion, many of the native species can still be considered common on Saipan and in fact some exhibit among the highest population densities for non-colonial birds.

\section{Trends}

Repeated measure comparisons identified significant change in bird densities between 1982 and 2007 for 10 of 13 species examined (Table 3). Densities had increased in Yellow Bittern, Island Collared-dove, White-throated Ground-dove, Micronesian Myzomela Myzomela rubratra, Micronesian Starling Aplonis opaca, and Eurasian Tree Sparrow. In addition, the Orangecheeked Waxbill had been introduced and became established on Saipan. Densities had decreased for Rufous Fantail, Nightingale Reed-warbler, and Golden White-eye.

Trends were stable in the remaining three species. By visually comparing the density estimates and their confidence intervals for the three surveys, it would seem that population densities had likely not changed in the Mariana Fruit-dove, Collared Kingfisher, and Bridled White-eye. Densities of Mariana Fruit-dove varied by $<2$ birds $\mathrm{km}^{-2}$ among the three surveys. Densities in Collared Kingfisher and Bridled White-eye were greater in 1997 than the other two surveys, significantly so for the Collared Kingfisher.

Given only three surveys, adequate power to detect a 50\% decline over 25 years was observed for all species except the Yellow Bittern, White-throated Ground-dove, Eurasian Tree Sparrow, 
Table 3. Repeated measures analysis of variance results for trends in Saipan bird densities among years, habitats, and year-habitat interaction fixed effects. Trends are denoted as increasing $(+)$, stable, or decreasing $(-)$. Significant changes are marked in bold. Dash indicates interaction test not conducted because one or both main effects results were non-significant. Degrees of freedom for the main effects are presented in parenthesis, and differences of least squares means for the significant effects are presented in Appendix 3 in Supplementary materials. Trend in Collared Kingfisher densities was not considered significant because the 1982 and 2007 estimates were not different, although both were lower than the 1997 estimate.

\begin{tabular}{|c|c|c|c|c|c|c|c|}
\hline \multirow[t]{3}{*}{ Species } & \multirow[t]{3}{*}{ Trend } & \multicolumn{6}{|l|}{ Fixed Effects } \\
\hline & & \multicolumn{2}{|l|}{ Year } & \multicolumn{2}{|l|}{ Habitat } & \multicolumn{2}{|l|}{ Interaction } \\
\hline & & $F$ & $P$ & $F$ & $P$ & $F$ & $P$ \\
\hline Yellow Bittern & + & $5 \cdot 93(2,557)$ & 0.003 & $1.89(5,531)$ & 0.095 & - & - \\
\hline Island Collared-dove & + & $6.43(2,569)$ & 0.002 & $1.79(5,376)$ & 0.115 & - & - \\
\hline White-throated Ground-dove & + & $49.22(2,589)$ & $<0.001$ & $2.91(5,408)$ & 0.013 & $3.05(10,644)$ & $<0.001$ \\
\hline Mariana Fruit-dove & stable & $0.33(2,549)$ & 0.721 & $13.41(5,472)$ & $<0.001$ & - & - \\
\hline Collared Kingfisher & stable & $5.03(2,573)$ & 0.007 & $1.50(5,387)$ & 0.190 & - & - \\
\hline Micronesian Myzomela & + & $6.32(2,566)$ & 0.002 & $17.44(5,431)$ & $<0.001$ & $3.04(10,614)$ & $<0.001$ \\
\hline Rufous Fantail & - & $32.62(2,551)$ & $<0.001$ & $10.95(5,432)$ & $<0.001$ & $3 \cdot 10(10,598)$ & $<0.001$ \\
\hline Nightingale Reed-warbler & - & $21.78(2,568)$ & $<0.001$ & $4.18(5,407)$ & 0.001 & $3.39(10,622)$ & $<0.001$ \\
\hline Bridled White-eye & stable & $2.24(2,537)$ & 0.107 & $12.12(5,361)$ & $<0.001$ & - & - \\
\hline Golden White-eye & - & $11.55(2,560)$ & $<0.001$ & $18.92(5,387)$ & $<0.001$ & $3.87(10,617)$ & $<0.001$ \\
\hline Micronesian Starling & + & $34.69(2,557)$ & $<0.001$ & $2.02(5,450)$ & 0.074 & - & - \\
\hline Eurasian Tree Sparrow & + & $72.45(2,539)$ & $<0.001$ & $49.29(5,395)$ & $<0.001$ & $16.16(10,592)$ & $<0.001$ \\
\hline Orange-cheeked Waxbill & + & $4.65(2,559)$ & 0.010 & $0.64(5,311)$ & 0.671 & - & - \\
\hline
\end{tabular}

and Orange-cheeked Waxbill (Table 4). Power was likely over-estimated for all species and should be viewed with caution. Typically, increasing the sampling frequency, conducting annual surveys for example, increases the regression CV because short-term trajectories and noise would be included in the time series. However, by increasing frequency of surveys, a more realistic pattern of population changes emerges over time by filling in the large temporal gaps of the time series. The current sampling effort of about 250 stations is adequate to calculate reliable estimates for

Table 4. Prospective power to detect a one-tailed decline in observed bird densities given a linear model, a constant $\mathrm{CV}$ in abundance, and a o.1 alpha-level. Power was considered adequate to detect trends at levels $>80 \%$ (in bold). The estimated number of stations $(K)$ needed to yield reliable CV levels (10\%) for each species was calculated using the mean number of stations sampled divided by the number of birds detected from the three surveys, $\overline{\left(k_{0} / n_{0}\right)}$, and assuming $b$ to be 3 . Highlighted text indicates adequate sampling to yield reliable CV levels ( $<$ current survey effort of 240 stations).

\begin{tabular}{|c|c|c|c|c|}
\hline Species & Regression CV & Power (\%) & $\overline{\left(k_{0} / n_{0}\right)}$ & K \\
\hline Yellow Bittern & 0.871 & 43 & 12.475 & 3743 \\
\hline Island Collared-dove & 0.159 & 100 & $5 \cdot 475$ & 1642 \\
\hline White-throated Ground-dove & 0.909 & 41 & 3.786 & 1136 \\
\hline Mariana Fruit-dove & 0.101 & 100 & 0.746 & 224 \\
\hline Collard Kingfisher & 0.304 & 97 & 0.896 & 269 \\
\hline Micronesian Myzomela & 0.093 & 100 & 0.777 & 233 \\
\hline Rufous Fantail & 0.175 & 100 & 0.400 & 120 \\
\hline Nightingale Reed-warbler & 0.073 & 100 & 1.547 & 464 \\
\hline Bridled White-eye & 0.104 & 100 & 0.156 & 47 \\
\hline Golden White-eye & 0.044 & 100 & 0.588 & 176 \\
\hline Micronesian Starling & 0.015 & 100 & 1.710 & 513 \\
\hline European Tree Sparrow & 0.638 & 59 & 1.200 & 360 \\
\hline Orange-cheeked Waxbill & 1.460 & 27 & 4.403 & 1321 \\
\hline
\end{tabular}


the Mariana Fruit-dove, Micronesian Myzomela, Rufous Fantail, Bridled White-eye, and Golden White-eye (Table 4). Roughly doubling the sampling effort would likely yield reliable CV levels for the Collared Kingfisher, Nightingale Reed-warbler, Micronesian Starling, and European Tree Sparrow. A substantial increase in effort ( $>$ four fold increase) would be needed to calculate densities with desired CV levels of 10\% for the Yellow Bittern, Island Collared-dove, Whitethroated Ground-dove, and Orange-cheeked Waxbill.

\section{Nightingale Reed-warbler}

A total of 595 Nightingale Reed-warblers was detected during the three surveys (Table 1). The population decreased from a high density of 58 birds km $\mathrm{km}^{-2}$ in 1982 to 40 birds km $\mathrm{km}^{-2}$ in 1997 and 22 birds $\mathrm{km}^{-2}$ in 2007 (Tables 2 and 3 ). The decline in densities of this endangered species is a specific concern.

Both a main-effects and interaction of habitat and year factors were significant predictors for Nightingale Reed-warbler density (Table 5). The interaction factor (habitats by years) should be used for making comparisons. We compared the densities for suitable habitat (open, secondary, and Tangantangan forests) versus less suitable habitat (golf course, limestone forest, and residential) while controlling for year using a contrasts statement. Densities were significantly different between suitable and less suitable habitats among the three years $\left(F_{3,711}=7.10\right.$, $P=0.0001$; Table 5). For example, densities have significantly declined in the residential habitat from 60 birds $\mathrm{km}^{-2}$ in 1982 to 13 birds $\mathrm{km}^{-2}$ in 1997 and continued to decline to 0.05 birds km $\mathrm{km}^{-2}$ in $2007\left(F_{1,469}=34.44, P<0.0001 ;\right.$ Table 5). This decline was also seen in the golf course habitat at a slightly lesser, but substantial, magnitude ( $92 \%$ and $89 \%$ decline, respectively).

\section{Discussion}

Our study presents the first quantitative data for land bird trends on Saipan. Comprehensive sampling across the whole island allowed us to make a quantitative assessment of population trends of 13 resident species. The study's main relevance is that it spans a 25 -year period of rapid economic development and habitat change on Saipan and therefore provides insights to ongoing changes in the status of the avifauna.

\section{Density and abundance estimates}

Before beginning a discussion of trend results it is worth remarking on several aspects of our analyses of population density and abundance. First, our density estimates for the 1982 data were up to three times larger than those calculated from the same data by Engbring et al. (1986). This

Table 5. Contrast of repeated measures ANOVA of Nightingale Reed-warbler densities by year and habitat suitability. Contrasts were used to test for differences between three suitable habitats versus three less suitable habitats by year. The contrasts revealed that densities were significantly different between suitable and less suitable habitats among the 3 years $\left(F_{3,711}=7.10, P=0.0001\right)$. Numbers of survey stations are included in parentheses.

\begin{tabular}{llll}
\hline Habitat & 1982 & 1997 & 2007 \\
\hline Suitable & & & \\
$\quad$ Open & $0.37 \pm 0.05(48)$ & $0.22 \pm 0.05(48)$ & $0.22 \pm 0.05(43)$ \\
$\quad$ Secondary Forest & $0.31 \pm 0.04(78)$ & $0.27 \pm 0.04(78)$ & $0.25 \pm 0.03(111)$ \\
$\quad$ Tangantangan Thicket & $0.40 \pm 0.04(62)$ & $0.46 \pm 0.04(61)$ & $0.27 \pm 0.05(47)$ \\
Less Suitable & & & \\
$\quad$ Golf Course & $0.38 \pm 0.11(10)$ & $0.15 \pm 0.11(10)$ & $0.04 \pm 0.11(11)$ \\
$\quad$ Limestone Forest & $0.18 \pm 0.07(23)$ & $0.18 \pm 0.07(24)$ & $0.08 \pm 0.06(29)$ \\
$\quad$ Residential & $0.60 \pm 0.07(23)$ & $0.13 \pm 0.06(23)$ & $0.05 \pm 0.06(32)$ \\
\hline
\end{tabular}


difference is due to the modern analytical methods we used, including incorporating covariate variables to adjust the detection function (Marques et al. 2007) and selecting different detection functions by pooling data from all of the surveys to develop an improved global detection function and applying it to raw counts (Johnson et al. 2006). Our estimates are more reliable because of the correction for missing individuals inherent in distance sampling. It is more than likely that using a more sophisticated survey design will even produce higher numbers.

Second, point-transect methods may not be appropriate for the Micronesian Megapode, a very rare bird. The Micronesian Megapode was not recorded in the last survey, and our findings lend credence to Craig's (1996) assertion that the megapode population on Saipan was declining. The Micronesian Megapode is much more common on some other Mariana Islands (U.S. Fish and Wildlife Service 1998c).

Lastly, all assumptions of the modelling may not have been met by some other species because of their behaviour. In particular, point transect counts may not be appropriate for the Guam Swiftlet because these rapidly flying active aerial foragers are inevitably counted closer to the observer than they were at the start of the count. Estimates of Bridled White-eye densities were very high, $>4,000$ birds $\mathrm{km}^{-2}$, and this is among the highest estimate for non-colonial birds. High densities of white-eyes may have 'swamped' the observers, causing observers to count individual birds multiple times. However, very high densities of island birds are not unheard of, for example, Micronesian Myzomela on Sarigan (Fancy et al. 1999), 'I'iwi Vestaria coccinea on Hawai'i Island, Hawai'i (Camp et al. 2009), and 'Apapane Himatione sanguinea (Ralph and Fancy 1995) also on Hawai'i Island occur at densities near to or greater than 3,00o birds km ${ }^{-2}$. These studies surveyed birds using point transect methods and an 8-min count period. Densities may be biased in the presence of bird movement. Buckland et al. (2008: S97) point out that that densities are overestimated during counts lasting several minutes where "some birds not initially present in the plot move into it during the recording period" and "birds within the plot are more likely to be detected when close to the point than when further away." A 'snapshot' or instantaneous count may be necessary for these highly mobile, vocal, and abundant species to meet model assumptions and produce unbiased estimates (Buckland et al. 2001, 2008; Buckland 2006).

\section{Trends}

A comparison of density estimates showed that the Yellow Bittern, Island Collared-dove, Whitethroated Ground-dove, Micronesian Myzomela, Micronesian Starling, Eurasian Tree Sparrow, and Orange-cheeked Waxbill were more abundant in 2007 than in 1982. Most of these species are fruit or seed eaters, or commensals with humans, and it would be relevant to ascertain how habitat alteration on the island has affected their status. Fruit-eating birds may have benefited from the expansion of scarlet gourd, which produces an edible red fruit. Three species - Mariana Fruit-dove, Collared Kingfisher, and Bridled White-eye - showed no apparent significant change in population density between 1982 and 2007. By comparison, the Rufous Fantail, Nightingale Reed-warbler, and Golden White-eye were less abundant than at the beginning of the study. These three species average much smaller in body size than the species with increasing trends, and they are insectivorous or predominantly insectivorous. We assume that land cover conversion from forest to anthropogenic-dominated habitats has facilitated declines in these species. Rufous Fantail and Nightingale Reed-warbler are reliant upon forested and grassland habitats, respectively, and they rarely nest or forage in residential habitats. Golden White-eyes forage on fruits in agricultural and urban habitats, and they nest in forested habitats. These forest-dependent birds may be declining because of habitat losses to development and scarlet gourd (Berger et al. 2005: 44, 45).

\section{Conservation implications}

Berger et al. (2005) developed a Comprehensive Wildlife Conservation Strategy to identify and prioritise conservation projects in CNMI. Priorities for land bird conservation were to minimise 
threats, specifically loss of habitat through land development; to implement Brown Tree Snake control and interdiction programmes; and to establish an efficient bird-monitoring programme.

Ameliorating threats is especially important for species experiencing population declines, such as Rufous Fantail, Nightingale Reed-warbler, and Golden White-eye. Protecting habitat and reducing the risk of depredation are two conservation approaches commonly prescribed for threatened and endangered insular species (e.g., U.S. Fish and Wildlife 1998b, Berger et al. 2005), and these actions may additionally benefit the more abundant bird species. More than 600 ha ( $>5 \%$ of the island area) have been designated with varying levels of protection for wildlife on Saipan, including the Bird Island Wildlife Conservation Area, Kagman Wildlife Conservation Area, and Saipan Upland Mitigation Bank (SUMB; Berger et al. 2005). Approximately 419 ha of the Marpi region was designated to the SUMB in 2002 and was established mainly to protect the Nightingale Reed-warbler (de Cruz and Williams 2003). Habitat within the SUMB is a mixture of native and secondary forest and Tangantangan thicket-meadow vegetation. Protecting these areas and habitats from development and degradation will benefit all native land birds, especially if habitat restoration and predator control are implemented.

The Brown Tree Snake decimated the avifauna on Guam within a few decades of its invasion (Savidge 1987, Wiles et al. 2003). Although extensive efforts have been implemented to prevent the spread of Brown Tree Snakes to the CNMI and elsewhere (see Colvin et al. 2005), there have been numerous Brown Tree Snake sightings on Saipan (Rodda and Savidge 2007). Continued interdiction of the Brown Tree Snake is essential because if the snake becomes established on Saipan it will cause the extirpation of most land birds.

In addition, at least two introduced predators further threaten land- and seabirds on Saipan: rats and feral cats. Three species of rat are already established on Saipan: the Pacific Rat Rattus exulans, the Brown Rat or Norway Rat $R$. norvegicus, and the Black Rat or Ship Rat R. rattus. These rats have been identified as a leading cause of bird extinctions and population suppression on islands worldwide (Atkinson 1985, Ashmole et al. 1994). On Saipan, Mosher (2006) noted that rats depredate adults and nests of the Nightingale Reed-warbler. Extensive control of rats may not be possible island-wide; however, controlling rats within protected areas such as the Bird Island Wildlife Conservation Area and SUMB would benefit Saipan's land birds. Cats can also deplete bird populations (e.g., Crooks and Soulé 1999). Educating citizens about cat impacts on wildlife may reduce depredation levels near residential areas, and local control may be possible (Kays and DeWan 2004).

\section{Monitoring implications}

This study provides an updated baseline of Saipan's land bird abundances, and it assesses the current status relative to previous estimates. Calculating up-to-date species' status is an important first step in developing a monitoring programme, and we make several suggestions that may be useful for improving the surveys.

Determining population trends is typically the primary goal of a monitoring programme (Camp et al. in press). This goal is achieved by setting realistic objectives that are based on measurable parameters, which in turn influence the sampling frequency, number of sampling units, and allocation of the sampling units. The three surveys analysed here used the same standardised point transect sampling method; however, several improvements could be made to improve future monitoring.

Additional surveys on Saipan, especially if they were more frequent, could provide the data needed to increase rigour of trend models, and they could strengthen the conclusions by identifying if the trends were of short- or long-term duration. Typically, by increasing sampling frequency by, for example, conducting surveys annually, uncertainty in the trend increases, because short-term trajectories and noise would be included in the time series. However, more frequent surveys do reveal a more realistic pattern of population changes over time by filling large temporal gaps in the time series. 
Precise population density estimates facilitate the ability to detect trends. Increasing the number of sampling stations may yield reliable CV levels (10\% uncertainty about the status estimates). Doubling the effort to about 500 stations should yield reliable CV levels for nine of the 13 species. Sampling effort would need to be more than quadrupled to yield reliable CV levels for the four remaining species. As a better alternative to simply doubling the sampling effort, we recommend allocating sampling proportional to one of the following three factors: density, variability, or extent of habitats. To facilitate detection of trends, it is advisable to allocate additional stations in the habitats with imprecise density estimates. In the Nightingale Reedwarbler case study below, we show how allocation of sampling stations can minimise variance.

\section{Nightingale Reed-warbler}

Even though densities of Nightingale Reed-warbler were low, using point transect methods to estimate reed-warbler status appears to be a good sampling technique. For our design, the detection function approximated the distance measures well and yielded precise density estimates (CVs of about $10-12 \%)$. The detection function model that best approximated the reed-warbler data met the model robustness, pooling robustness, shape criterion, and estimator efficiency properties necessary for generating reliable estimates. This allowed for pooling the data across observers and years to surpass the recommended minimum numbers of detections (around 100) and improved model performance. In addition, if the shape criterion (the detection function possesses a 'shoulder' near the point) is maintained and other problems (e.g., violations of assumptions) are minimised, data from future surveys may also be pooled to produce reliable estimates even when the minimum numbers of detections are not recorded (Buckland et al. 2001). This would be important if reed-warbler numbers continue to decline and counts yield fewer detections to work with. Thus, point transect sampling as it has been conducted on Saipan appears to be a reliable method for calculating Nightingale Reed-warbler status at the island-wide scale. However, an 8-min count period may yield biased estimates and shorter count durations, including instantaneous counts, should be investigated (Buckland 2006, Lee and Marsden 2008).

Approximately doubling the number of stations sampled, from 240 to 470 stations, would yield reliable CV levels (10\%) about the status estimates for the Nightingale Reed-warbler. The $2007 \mathrm{CV}$ was only $12 \%$, very close to a satisfactory desired level. Allocating sampling stations proportional to the precision of reed-warbler estimates by habitat is more effective than simply doubling the number of stations. Allocating 158 stations to the golf course (40 stations), limestone forest ( 70 stations), and residential (48 stations) habitats should reduce the variability of density estimates and is likely to maintain precise estimates even with continued loss of reed-warblers. If additional sampling stations can be surveyed, then they should be allocated in open, Tangantangan thicket, and limestone forest habitats. Allocating more stations to the first two habitats, which are optimal for reed-warblers, would benefit precision levels for reed-warbler density estimates. Allocating additional stations in limestone forest habitat should benefit estimates for all land birds.

An important point was that three surveys over 25 years were not adequate for using regression modelling to determine the trend of the Nightingale Reed-warbler. Surveying frequency should occur at an interval that appropriately reflects large shifts in population trajectories (Peterjohn et al. 1995). The current time series does not reveal short-term deviations from the long-term trend. Thus, more frequent surveys are needed, and the survey frequency should be based on a balance of survey costs and the likelihood of detecting a declining trend.

Furthermore, this sampling technique does not yield information on causes of population change. For target species, such as reed-warblers, studies are needed to ascertain the environmental factors and management actions that directly affect demographic parameters, especially survival and fecundity. Such research could more promptly identify population changes and identify remedial actions to be implemented. In addition to population monitoring, ecological research that measures changes in area of habitat types, compares densities between areas with and 
without gourd infestation, and investigates autecology of particular bird species are needed to understand how populations are responding to habitat alteration.

\section{Acknowledgements}

This study was produced by the Hawaii Forest Bird Interagency Database Project of the Pacific Island Ecosystems Research Center (PIERC), U.S. Geological Service. The CNMI Division of Fish and Wildlife, U.S. Fish and Wildlife Service, and PIERC funded this study. We thank the field biologists who organised and collected the data: C. Aguon, F. Amidon, P. Ashman, J. Engbring, J. Lepson, A. Marshall, G. Martin, P. Pyle, N. Shema, P. Radley, M. Reynolds, and L. Williams. Also, we thank those who cut transects, especially R. Sikkel. The following reviewers helped improve the manuscript: T. Diamond, G. Dutson, P. M. Gorresen, J. Hatfield, R. Holden, F. Huettmann, S. Kremer, S. Marsden, and L. Mehrhoff. Any use of trade, product, or firm names in this publication is for descriptive purposes only and does not imply endorsement by the U.S. Government.

\section{References}

American Ornithologists' Union. (1983) Check-list of North American birds. $7^{\text {th }}$ Edition. Washington, D.C.: American Ornithologist's Union.

Ashmole, N. P., Ashmole, M. J. and Simmons, K. E. L. (1994) Seabird conservation and feral cats on Ascension Island, South Atlantic. Pp. 94-121 in D. N. Nettleship, J. Burger and M. Gochfeld, eds. Seabirds on islands: threats, case studies and action plans. Cambridge, UK: BirdLife International. Bird Conservation Series 1.

Atkinson, I. A. E. (1985) The spread of commensal species of Rattus to oceanic islands and their effect on island avifaunas. Pp. 35-81 in P. J. Moors, ed. Conservation of island birds. Cambridge, UK: International Council for Bird Preservation.

Berger, G. M., Gourley, J. and Schroer, G. (2005) Comprehensive wildlife conservation strategy for the Commonwealth of the Northern Mariana Islands. Saipan, MP: Division of Fish and Wildlife, Department of Lands and Natural Resources, Commonwealth of the Northern Mariana Islands.

BirdLife International. (2000) Threatened birds of the world. Barcelona and Cambridge, UK: Lynx Edicions and BirdLife International.

Buckland, S. T. (2006) Point transect surveys for songbirds: robust methodologies. Auk 123: 345-357.

Buckland, S. T., Anderson, D. R., Burnham, K. P., Laake, J. L., Borchers, D. L and Thomas, L.
(2001) Introduction to distance sampling: estimating abundance of biological populations. Oxford: Oxford University Press.

Buckland, S. T., Marsden, S. J. and Green, R. E. (2008) Estimating bird abundance: making methods work. Bird Conserv. Internatn. 18: S91-S108.

Camp, R. J., Pratt, T. K., Gorresen, P. M., Jeffrey, J. J. and Woodworth, B. L. (2009) Passerine bird trends at Hakalau Forest National Wildlife Refuge, Hawai'i. University of Hawai'i at Hilo: Hawai'i Cooperative Studies Unit Technical Report HCSU-OII.

Camp, R. J., Reynolds, M. H., Gorresen, P. M., Pratt, T. K. and Woodworth, B. L. (In press) Monitoring Hawaiian forest birds. In T. K. Pratt, B. L. Woodworth, C. T. Atkinson, J. Jacobi and P. Banko, eds. Conservation biology of Hawaiian forest birds: implications for insular avifauna. New Haven, CT: Yale University Press.

Colvin, B. A., Fall, M. W., Fitzgerald, L. A. and Loope, L. L. (2005) Review of brown treesnake problems and control programs: report of observations and recommendations. Unpublished report to the U.S. Department of Interior, Office of Insular Affairs, March 2005.

Craig, R. J. (1992) Territoriality, habitat use, and ecological distinctness of an endangered Pacific island reed-warbler. J. Field Ornithol. 63: 436-444.

Craig, R. J. (1996) Seasonal population surveys and natural history of a Micronesian 
bird community. Wilson Bull. 108: 246267.

Crooks, D. R., and Soulé, M. E. (1999) Mesopredator release and avifaunal extinctions in a fragmented system. Nature 400 : 563-566.

de Cruz, J. and Williams, L. (2003) Baseline avian and vegetation surveys of the Saipan Upland Mitigation Bank 1999-2003. CNMI Division of Fish and Wildlife, Technical Report \#13.

Di Stefano, J. (2003) How much power is enough? Against the development of an arbitrary convention for statistical power calculations. Funct. Ecol. 17: 707-709.

Engbring, J., Ramsey, F. L. and Wildman, V. J. (1986) Micronesian forest bird survey, 1982: Saipan, Tinian, Aguijan, and Rota. U.S. Fish and Wildlife Service Report.

Falanruw, M. C., Cole, T. G. and Ambacker, A. H. (1989) Vegetation survey of Rota, Tinian, and Saipan, Commonwealth of the Northern Mariana Islands. USDA For. Serv. Resource Bull. PSW-27.

Fancy, S. G., Craig, R. J. and Kessler, C. W. (1999) Forest bird and fruit bat populations on Sarigan, Mariana Islands. Micronesica 31: $247-254$.

Gerrodette, T. (1987) A power analysis for detecting trends. Ecology 68: 1364-1372.

Gerrodette, T. (1991) Models for power of detecting trends - a reply to Link and Hatfield. Ecology 72: 1889-1892.

Huettmann, F. and Czech, B. (2006) The steady state economy for global shorebird and habitat conservation. Endang. Species Res. 2: 89-92.

Johnson, L., Camp, R. J., Brinck, K. W. and Banko, P. C. (2006) Long-term population monitoring: lessons learned from an endangered passerine in Hawai'i. Wildl. Soc. Bull. 34: 1055-1063.

Johnson, N. C. (2003) Presence of the Orangecheeked Waxbill (Estrilda melpoda) on Saipan, Northern Mariana Islands. Unpublished report submitted to the U.S. Fish and Wildlife Service, Pacific Islands Office, December 2003.

Kays, R. W. and DeWan, A. A. (2004) Ecological impact of inside/outside house cats around a suburban nature preserve. Anim. Conserv. 7: 273-283.
Lee, D. C. and Marsden, S. J. (2008) Adjusting count period strategies to improve the accuracy of forest bird abundance estimates from point transect distance sampling surveys. Ibis 2: 315-325.

Littell, R. C., Milliken, G. A., Stroup, W. W. and Wolfinger, R. D. (1996) SAS system for mixed models. Cary, NC: SAS Institute Inc.

Liu, Z. and Fischer, L. (2006) Commonwealth of the Northern Mariana Islands vegetation mapping using very high spatial resolution imagery - methodology. USDA Forest Service, Pacific Southwest Region, Forest Health Protection. http://www.fs. fed.us/r5/spf/fhp/fhm/landcover/islands/ index.shtml

Marques, F. F. C. and Buckland, S. T. (2004) Covariate models for the detection function. Pp. $31-47$ in S. T. Buckland, D. R. Anderson, K. P. Burnham, J. L. Laake, D. L. Borchers, and L. Thomas, eds. Advanced distance sampling. Oxford: Oxford University Press.

Marques, T. A., Thomas, L., Fancy, S. G. and Buckland, S. T. (2007) Improving estimates of bird density using multiple-covariate distance sampling. Auk 124: 1229-1243.

Mosher, S. M. (2006) Ecology of the endangered Nightingale Reed-Warbler (Acrocephalus luscinia) on Saipan, Micronesia. Master's thesis, University of Idaho, Moscow, ID.

Peterjohn, B. G., Sauer, J. R. and Robbins, C. S. (1995) Population trends from the North American breeding bird survey. Pp. 3-39 in T. E. Martin and D. M. Finch, eds. Ecology and management of Neotropical migratory birds: a synthesis and review of the critical issues. Oxford: Oxford University Press.

Ralph, C. J. and Fancy, S. G. (1995) Demography and movements of Apapane and Iiwi in Hawaii. Condor 97: 729-742.

Reichel, J. D. and Glass, P. O. (1991) Checklist of the birds of the Mariana Islands. 'Elepaio 51: 3-11.

Reichel, J. D., Wiles, G. J. and Glass, P. O. (1992) Island extinctions: the case of the endangered Nightingale Reed-Warbler. Wilson Bull. 104: 44-54.

Rodda, G. H. and Savidge, J. A. (2007) Biology and impacts of Pacific island invasive species. 2. Bioga irregularis, the Brown 
Tree Snake (Reptilia: Columbridae). Pac. Sci. 61: 307-324.

Savidge, J. A. (1987) Extinction of an island forest avifauna by an introduced snake. Ecology 68: 66o-668.

Stattersfield, A. J., Crosby, M. J., Long, A. J. and Wege, D. C. (1998) Endemic bird areas of the world: priorities for biodiversity conservation. Cambridge, UK: BirdLife International. BirdLife Conservation Series No. 7.

Thomas, L., Laake, J. L., Strindberg, S., Marques, F. F. C., Buckland, S. T., Borchers, D. L., Anderson, D. R., Burnham, K. P., Hedley, S. L., Pollard, J. H., Bishop, J. R. B. and Marques, T. A. (2006) Distance 5.0. Release 2. Research Unit for Wildlife Population Assessment, University of St. Andrews, U.K. http://www.ruwpa.st-and.ac.uk/ distance/.

U.S. Bureau of the Census. (1981) 1980 Census of Population, Volume 1, Part 57B. Saipan, MP: U.S. Bureau of the Census.

U.S. Census Bureau. (2001) Census Bureau releases census: 2000 population counts for the Commonwealth of the Northern Ma- riana Islands. Press Release, July 3, 2001. Saipan, MP: U.S. Census Bureau.

U.S. Fish and Wildlife Service. (1998a) 1997 forest bird survey, Saipan, CNMI: nightingale reed-warbler (Acrocephalus luscinia) assessment. Honolulu, HI: USFWS Unpublished report, December 1998.

U.S. Fish and Wildlife Service. (1998b) Recovery plan for the nightingale reed-warbler. Portland, OR: U.S. Fish and Wildlife Service.

U.S. Fish and Wildlife Service. (1998c) Recovery plan for the Micronesian Megapode (Megapodius laperouse laperouse). Portland, OR: U.S. Fish and Wildlife Service.

U.S. Fish and Wildlife Service. (2004) Report to Congress on the recovery of threatened and endangered species: fiscal years 20032004. Washington, D.C.: U.S. Fish and Wildlife Service.

Wiles, G. J., Bart, J., Beck, Jr., R. E., and Aguon, C. F. (2003) Impacts of the Brown Tree Snake: patterns of decline and species persistence in Guam's avifauna. Conserv. Biol. 17: 1350-1360.

\section{RICHARD J. CAMP*}

U.S. Geological Survey, Hawai'i Cooperative Studies Unit, P.O. Box 44, Hawaii National Park, HI 96718 , U.S.A.

\section{THANE K. PRATT}

U.S. Geological Survey, Pacific Island Ecosystems Research Center, P.O. Box 44, Hawaii National Park, HI 96718, U.S.A.

\section{ANN P. MARSHALL, FRED AMIDON}

U.S. Fish and Wildlife Service, Pacific Islands Office, 300 Ala Moana Boulevard, Honolulu, HI 96850, U.S.A.

\section{LAURA L. WILLIAMS}

Commonwealth of the Northern Mariana Islands Division of Fish and Wildlife, Department of Lands and Natural Resources, P. O. Box 10007, Saipan, MP 96950.

*Author for correspondence; e-mail: rick_camp@usgs.gov 